\title{
Influence of Selected Antidepressants on the Ciliated Protozoan Spirostomum ambiguum: Toxicity, Bioaccumulation, and Biotransformation Products
}

\author{
Grzegorz Nałęcz-Jawecki ${ }^{1, *}$, Milena Wawryniuk ${ }^{1}$, Joanna Giebułtowicz ${ }^{2} \oplus$, Adam Olkowski ${ }^{1}$ \\ and Agata Drobniewska $1, *$ (i) \\ 1 Department of Environmental Health Sciences, Faculty of Pharmacy, Medical University of Warsaw, \\ ul. Banacha 1, 02-097 Warszawa, Poland; mwawryniuk@wum.edu.pl (M.W.); olek_adam@interia.pl (A.O.) \\ 2 Department of Bioanalysis and Drugs Analysis, Faculty of Pharmacy, Medical University of Warsaw, \\ ul. Banacha 1, 02-097 Warszawa, Poland; jgiebultowicz@wum.edu.pl \\ * Correspondence: gnalecz@wum.edu.pl (G.N.-J.); agata.drobniewska@wum.edu.pl (A.D.); \\ Tel.: +48-22-572-0795 (G.N.-J.); Tel./Fax: +48-22-572-0740 (A.D.)
}

Academic Editor: Jolanta Kumirska

Received: 21 February 2020; Accepted: 20 March 2020; Published: 25 March 2020

check for updates

\begin{abstract}
The present study aimed to evaluate the effect of the most common antidepressants on aquatic protozoa. Spirostomum ambiguum was used as the model protozoan. The biological activity of four antidepressants, namely fluoxetine, sertraline, paroxetine, and mianserin, toward S. ambiguum was evaluated. Sertraline was found to be the most toxic drug with $\mathrm{EC}_{50}$ values of 0.2 to $0.7 \mathrm{mg} / \mathrm{L}$. The toxicity of the antidepressants depended on the $\mathrm{pH}$ of the medium and was the highest in alkaline conditions. Sertraline was also the most bioaccumulating compound tested, followed by mianserin. Slow depuration was observed after transferring the protozoa from the drug solutions to a fresh medium, which indicated possible lysosomotropism of the tested antidepressants in the protozoa. The biotransformation products were identified using a high-resolution mass spectrometer after two days of incubation of the protozoa with the tested antidepressants. Four to six potential biotransformation products were observed in the aqueous phase, while no metabolites were detected in the protozoan cells. Because of the low abundance of metabolites in the medium, their structure was not determined.
\end{abstract}

Keywords: Spirotox; fluoxetine; sertraline; paroxetine; mianserin; pharmaceuticals in the environment

\section{Introduction}

Protozoa play an important role in the aquatic food web as primary consumers. They are common in surface waters and activated sludge in waste-water treatment plants (WWTP), where they feed on bacteria and may ingest pollutants directly from water. Spirostomum ambiguum is one of the largest ciliated protozoa with long generation time of about $70 \mathrm{~h}$. It tolerates $\mathrm{pH}$ changes from 5.5 to 8.0 , can be cultured in laboratory, and stored in an inorganic medium for at least eight days [1]. Thus, it is a very convenient organism and has been used in ecotoxicological studies for more than 25 years [1-3].

Antidepressants are one of the major group of pharmaceuticals used worldwide. Sertraline, fluoxetine, and paroxetine, belonging to the most commonly used selective serotonin re-uptake inhibitors (SSRIs), were ranked 14, 31, and 68, respectively, on the top 300 best-selling drugs in 2020 with 38.3, 21.9, and 11.7 million prescriptions, respectively, in the U.S. in 2017 (www.clincalc.com, accessed: 7 February 2020). Mianserin is an atypical, tetracyclic antidepressant used for the treatment of major depressive disorders. Antidepressants, as with other pharmaceutically active compounds (PhACs), are released into freshwaters mainly with waste-water, and they have been detected in 
effluents, freshwaters, and even drinking waters in many countries [4-9]. Mole and Brooks [10] wrote a comprehensive review of the occurrence of SSRIs in the environment. They found that fluoxetine, citalopram, paroxetine, and sertraline, and their main metabolites norfluoxetine and norsertraline were the most commonly detected antidepressants. Their concentrations in influents and effluents were up to several $\mu \mathrm{g} / \mathrm{L}$. SSRIs have been identified not only in water and sediments but also in fish caught in the effluent waste streams and in molluscs and fish tissues commonly consumed by humans [11]. Most of the SSRIs are slowly degraded under the influence of both biotic and abiotic factors, and due to the continuous discharge are called pseudo-persistent contaminants [11].

High biological activity of antidepressants, especially SSRIs, has been reported for algae [12] and crustaceans and fish [11]. In short-term acute toxicity tests, the $\mathrm{EC}_{50}$ values ranged from 0.2 to $10 \mathrm{mg} / \mathrm{L}[11,12]$. However, in chronic toxicity assays, the lowest observed effect concentration (LOEC) values were much lower, as low as $0.0136 \mathrm{mg} / \mathrm{L}$ for Pseudokirchneriella subcapitata [12]. Moreover, SSRIs are considered to be potentially bioaccumulative [13]. They were detected in fish [14,15] and bivalve [16] tissues. Sertraline was the most bioaccumulating compound in the effluent reach stream [17]. Its bioaccumulation factor (BCF) in two benthic organisms Hydropsyche sp. and Erpobdella octoculata ranged from 920 to $2100 \mathrm{~L} / \mathrm{kg}$ and was close to the predicted value. There is a lack of knowledge of the response of protozoa to PhACs, probably due to their small size that entails the use of more sophisticated research techniques.

The analysis of the occurrence of PhACs and their human metabolites in the environment has been restricted to compounds with standards available in the market $[8,10,18]$. With the development of new analytical mass spectrometers, i.e., Quadrupole time of flight (QTOF) working in all ion MS/MS modes and high-resolution Orbitrap ${ }^{\mathrm{TM}}$, it has become possible to detect a huge amount of non-target PhAC metabolites and transformation products $[18,19]$ not only of human origin but also of microbial origin. However, neither PhAC nor their metabolites have yet been reported for their effect on protozoa. Some antidepressant metabolites, e.g., norfluoxetine, have even higher biological activity as parent compounds [20]. Thus, to recognize the complete risk of drugs occurring in the aquatic environment, it is important to know both biotic and abiotic transformation of these compounds.

The present study aimed to evaluate the biological activity of four antidepressants, namely fluoxetine, sertraline, paroxetine and mianserin, on the ciliated protozoan S. ambiguum. Our comprehensive study included analysis of acute toxicity, bioconcentration, and biotransformation. Acute toxicity was evaluated with the prolonged, seven-day Spirotox assay. As the tested compounds ionize in water solution, three $\mathrm{pH}$ levels from the range of the $\mathrm{pH}$ of natural freshwaters $(6.0,6.5$ and 7.4) were tested, and the relationship between $\mathrm{pH}$ and toxicity was discussed. The bioconcentration of the tested pharmaceuticals was analyzed in the six days uptake followed by six days depuration phases, while the biotransformation products were identified after two days of incubation of the protozoa with the tested antidepressants. In the bioconcentration tests, high-performance liquid chromatography (HPLC) with the mass spectrometer detector QTRAPTM was used, while in the biotransformation tests, UPLC with MS/MS Orbitrap ${ }^{\mathrm{TM}}$ was applied with post facto analysis performed by Compound Discoverer Software (Thermo Fisher Scientific, Waltham, MA). To the best of our knowledge, this is the first study on the bioaccumulation and possible biotransformation of PhACs by protozoa.

\section{Results}

\subsection{Toxicity}

The protozoan S. ambiguum could be stored in an inorganic medium for a long time without losing its viability; thus, the Spirotox test could be prolonged up to seven days. In all tests, the toxic effect percent in the negative control was less than $10 \%$; thus, the results of the tests were valid.

Sertraline was the most toxic antidepressant in all the tested approaches, with $\mathrm{EC}_{50}$ in the range of $0.2-0.7 \mathrm{mg} / \mathrm{L}$ (Figure 1 and Table A1). Paroxetine and fluoxetine were three-fold, while mianserin was 10 -fold less toxic than sertraline. The tested compounds were acutely toxic to S. ambiguum, as the 
$\mathrm{LC}_{50}$ and $\mathrm{EC}_{50}$ values were close to each other. This implies that sublethal effects quickly became lethal ones. Moreover, in most cases, the $\mathrm{EC}_{20}$ values were less than two times lower than $\mathrm{EC}_{50}$ values (Table A1). Only for fluoxetine and mianserin tested at $\mathrm{pH}$ lower than seven, the $\mathrm{EC}_{50}$ to $\mathrm{EC}_{20}$ ratio was higher than two. $\mathrm{EC}_{20}$ is a threshold value that indicates the threat to the population of the tested organism. This implies that the $\mathrm{EC}_{50}$ value is a good predictive value that can be used to predict the effects of the substances on an entire population. As expected, the toxicity increased with the time of incubation, and the seven-day values were much lower than the one- and the two-day values. The toxicity also depended on the $\mathrm{pH}$ of the medium. S. ambiguum could be tested in a wide range of $\mathrm{pH}$ from 5.5 to 8.0. The toxicity was measured at three $\mathrm{pH}$ values $6.0 ; 6.5$ and 7.4 to imitate natural freshwaters. For all tested antidepressants, an increase in toxicity was observed with increasing $\mathrm{pH}$. For SSRIs, the step change can be seen between $\mathrm{pH} 6.0$ and 6.5, while for mianserin, the toxicity increased gradually with the increase in $\mathrm{pH}$, especially after one and two days of incubation. The relationship between toxicity and $\mathrm{pH}$ of the medium was previously reported for nitrophenols [21], and to the best of our knowledge, this relationship has not been tested for pharmaceuticals thus far. The toxicity-to-water $\mathrm{pH}$ relationship has two consequences. First, the $\mathrm{pH}$ of the water should be more strictly defined in the ecotoxicity guidelines to prevent high variability of the results. The present data indicate that the $\mathrm{pH}$ shift by only one unit may result in a significant change in toxicity. Second, $\mathrm{pH}$ of the water and effluent should be considered in the environmental risk assessment of the ionizable compounds. The tested antidepressants are cationic amphiphilic drugs that ionize in acidic solutions, and the bioavailability of the ionized form of the compound is lower than that of the non-ionized one. For many amphiphilic compounds, the biological activity may be predicted using the $\mathrm{pH}$-dependent water/octanol partition coefficient $(\log \mathrm{D})$ instead of $\log$ P. Taking into account the whole group of compounds tested there was no correlation between the toxicity of the antidepressants to S. ambiguum and lipophilicity expressed by both $\log \mathrm{P}$ and $\log \mathrm{D}$ coefficients (Table 1). Thus, their biological activity cannot be explained by the simple non-polar and polar narcosis mechanism of action [22]. The tested drugs inhibit neurotransmitter's (serotonin) re-uptake in vertebrate's tissues. Minguez et al. [23] reported the correlation of SSRI toxicity towards Daphnia with the log P coefficient. However, they also observed irreversible cell lysis in the abalone hemocytes, probably due to interactions between the drugs and lysosomal membrane phospholipids [23]. As vacuolization was the first symptom of toxicity of the tested compounds in S. ambiguum, we expected that such interactions also occur in protozoa and are the main reason of toxic effects.

Table 1. Physicochemical characteristics of the tested antidepressants.

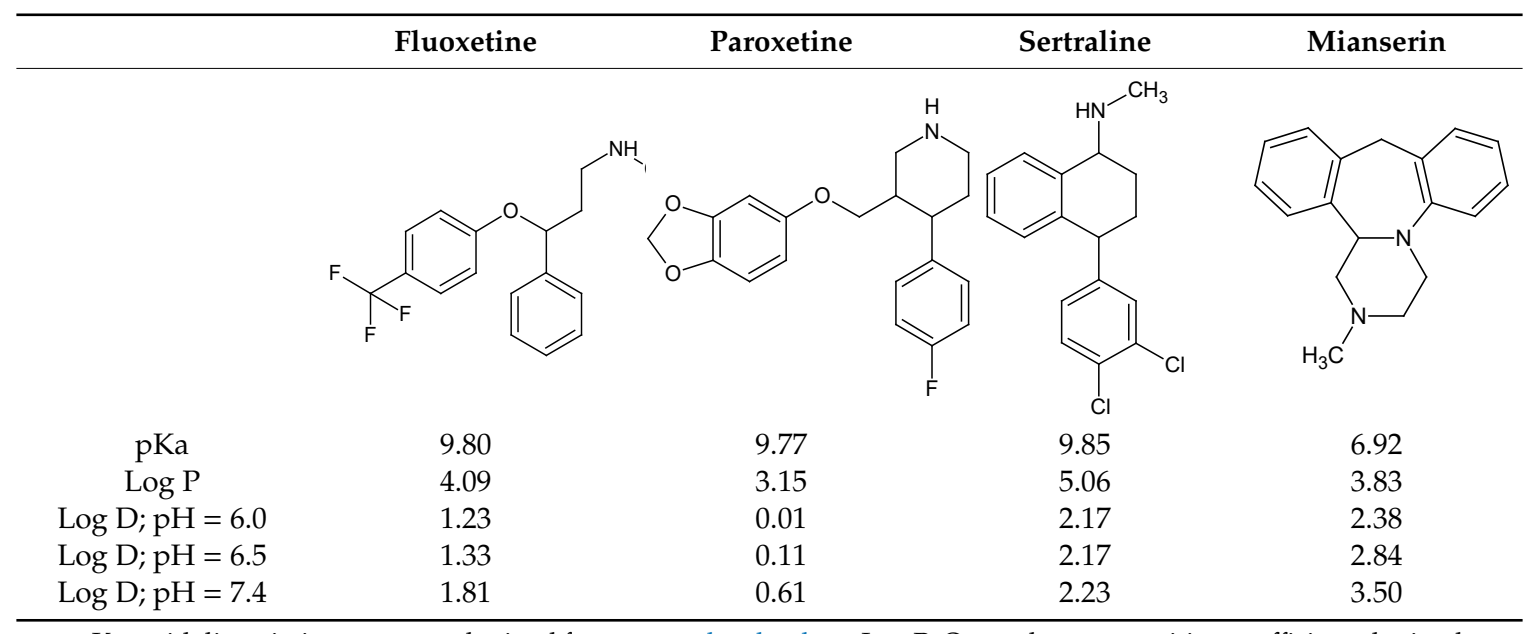

pKa: acid dissociation constant obtained from www.drugbank.ca; Log P: Octanol-water partition coefficient obtained from www.drugbank.ca; Log D: pH-dependent octanol-water partition coefficient calculated with logD predictor (KLOP algorithm, MarvinSketch 15.2.23. software (https://disco.chemaxon.com/apps). 


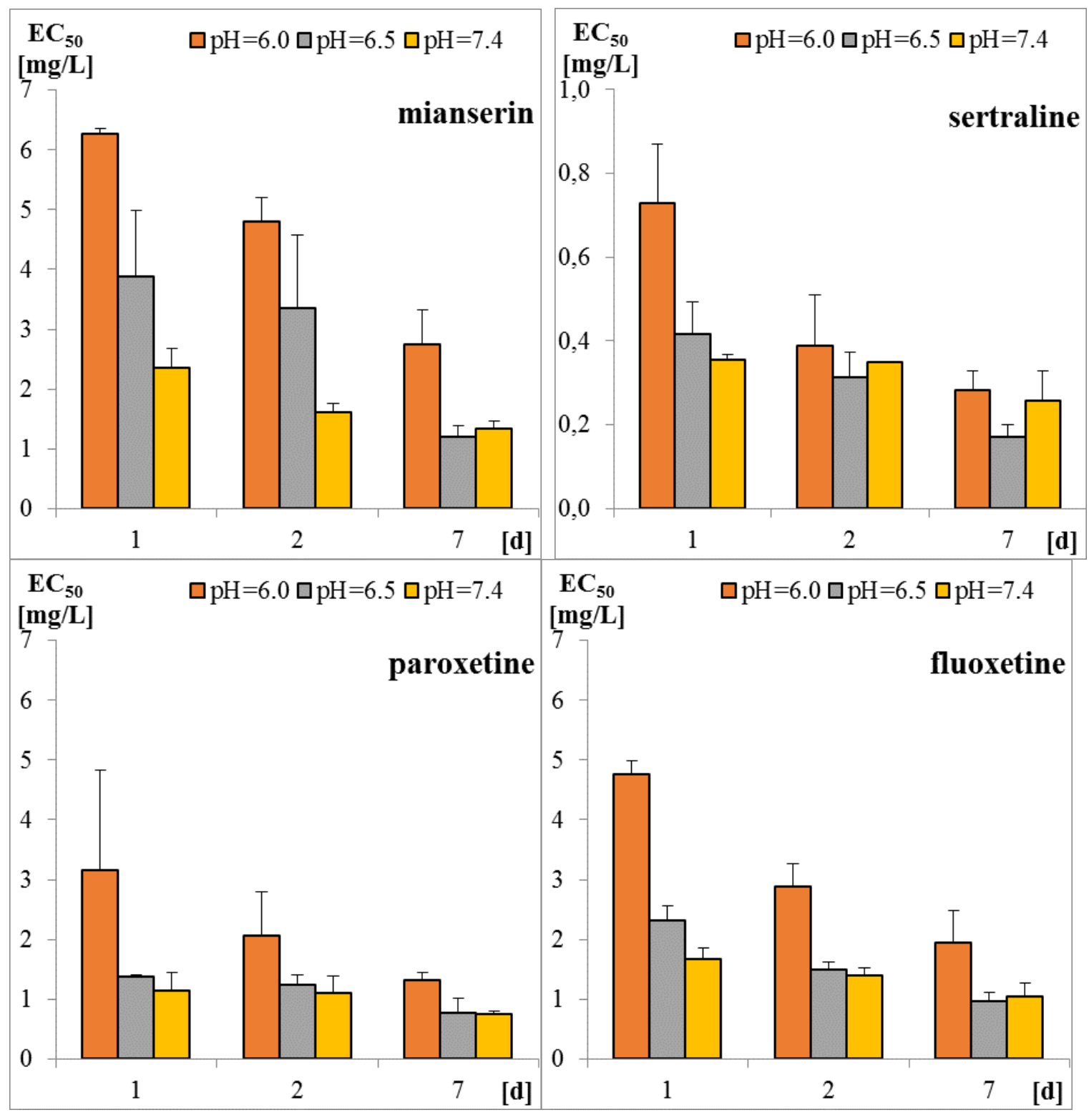

Figure 1. Toxicity of tested antidepressants in Spirotox test after 1, 2, and 7 days incubation $\left(\mathrm{EC}_{50}\right.$ expressed in $\mathrm{mg} / \mathrm{L})$.

Antidepressants, especially sertraline, are very potent against parasitic protozoa with $\mathrm{IC}_{50}$ of $0.16 \mathrm{mg} / \mathrm{L}$ and $0.24 \mathrm{mg} / \mathrm{L}$ for Plasmodium falciparum and Trypanosoma brucei rhodosiensis, respectively, and are considered to be applicable in the treatment of relevant tropical diseases caused by these parasites [24]. Palit and Ali [25] reported high activity of sertraline against another parasite protozoan Leishmania donovani. They hypothesized that sertraline induces cell apoptosis by lowering adenosine triphosphate (ATP) levels, resulting in a reduction in oxygen consumption. However, more research is needed to prove this hypothesis and to determine the mode of action of antidepressants towards protozoa.

The protozoan S. ambiguum appeared to be comparably sensitive as other organisms used in acute toxicity bioassays. Similar to our results, sertraline was reported to be the most toxic antidepressant to crustaceans with $48-\mathrm{h} \mathrm{LC}_{50}$ of $0.12 \mathrm{mg} / \mathrm{L}$ for Ceriodaphnia dubia [26], 24-h $\mathrm{LC}_{50}$ of $0.6 \mathrm{mg} / \mathrm{L}$ for Thamnocephalus platyurus [27] and 48-h EC 50 of $0.92 \mathrm{mg} / \mathrm{L}$ for Daphnia magna [28]. Slightly lower toxicity was reported for fluoxetine, ranging from 0.23 and $0.82 \mathrm{mg} / \mathrm{L}$ for C. dubia and D. magna [12] to $0.85 \mathrm{mg} / \mathrm{L}$ for T. platyurus [29]. Contrary to the previous two antidepressants, paroxetine was 
10-fold less toxic to D. magna (6.3 mg/L) [28] than to C. dubia $(0.58 \mathrm{mg} / \mathrm{L})$ [26]. Very little information is available for mianserin. Wawryniuk et al. [30] reported 24-h $\mathrm{LC}_{50}$ of $1.8 \mathrm{mg} / \mathrm{L}$ for T. platyurus, while Minguez et al. [23] showed 48-h $\mathrm{EC}_{50}$ of $7.81 \mathrm{mg} / \mathrm{L}$ for D. magna. Similar acute toxicity data were reported for fish: $48-\mathrm{h} \mathrm{LC}_{50}$ of $0.198 \mathrm{mg} / \mathrm{L}$ for fluoxetine towards Pimephales promelas [31] and 96-h $\mathrm{LC}_{50}$ of $0.38 \mathrm{mg} / \mathrm{L}$ for sertraline towards Oncorhynchus mykiss [27]. These values are 2-3 orders of magnitude higher than the levels of antidepressants detected in municipal effluents and freshwaters, and therefore, the acute toxicity effect is not expected in the environmental samples.

\subsection{Bioaccumulation}

To evaluate bioaccumulation of the tested antidepressants in protozoa, S. ambiguum was incubated with the antidepressants at three concentrations: low $(10 \mu \mathrm{g} / \mathrm{L})$, medium $(25 \mu \mathrm{g} / \mathrm{L})$, and high $(100 \mu \mathrm{g} / \mathrm{L})$ for six days uptake phase, followed by six days depuration phase.

Whole-body internal concentrations based on the parent compound were measured. The concentrations of the compounds inside the protozoa and in the medium were determined four times in each research phase. The results of the concentration of the tested antidepressants in S. ambiguum cells and in the medium are shown in Figure 2 and Table A2, while the BCF values are presented in Figure 3 and Table A3. From the internal concentration data, it can be concluded that uptake and elimination kinetics vary greatly between the tested pharmaceuticals. S. ambiguum accumulated significant amounts of sertraline and mianserin, but different bioaccumulation scenarios were observed in each case and for each drug concentration. The concentration of sertraline in the protozoan cells increased gradually during the uptake phase for low and medium drug concentration. For the highest level tested, the highest sertraline concentration was determined after $24 \mathrm{~h}$, followed by a gradual decrease in its concentration. In the depuration phase, the sertraline intracellular concentration remained at a high level, falling by only $40 \%$ of the highest concentration (all tested concentrations). Mianserin reached its highest concentration in S. ambiguum cells after two days of incubation. After six days, its level dropped to $60-70 \%$ and then gradually decreased in the depuration phase. Fluoxetine and paroxetine were not accumulated inside the protozoan cells, and their BCF values during the uptake phase never exceeded $1000 \mathrm{~L} / \mathrm{kg}$, while for mianserin and sertraline, the BCF values reached much higher at 4939 and 34,092 L/kg, respectively. The U.S. Environmental Protection Agency has established a BCF ranging from 100 to $1000 \mathrm{~L} / \mathrm{kg}$ to indicate a medium concern for bioaccumulation [13]; compounds with BCF > $1000 \mathrm{~L} / \mathrm{kg}$ are considered to be highly bioaccumulating.

The bioaccumulation of SSRIs has been reported in invertebrates and fish by many authors [17,32-34], and the results varied depending on the species. The BCF for sertraline calculated by Grabicova et al. [17] for E. octoculata and Hydropsyche sp. was higher than $2000 \mathrm{~L} / \mathrm{kg}$, while Du et al. [32] found that the BCF value for Planorbid sp. was only $990 \mathrm{~L} / \mathrm{kg}$. These values were an order of magnitude lower than our results obtained for S. ambiguum. The largest spread of results was published for fluoxetine. The value close to our value was obtained by Franzellitti et al. [33] in the marine mussel Mytilus galloprovincialis; after seven days of treatment at the concentrations of 30 and $300 \mathrm{ng} / \mathrm{L}$, the BCF ranged from 200 to $800 \mathrm{~L} / \mathrm{kg}$. A higher value of $3000 \mathrm{~L} / \mathrm{kg}$ was reported by Du et al. [32] for Planorbid sp. In contrast, Meredith-Williams et al. [34] obtained quite different BCF values of 185,900 L/kg and $1387 \mathrm{~L} / \mathrm{kg}$ in freshwater shrimp (Gammarus pulex) and the water boatman (Notonecta glauca), respectively. According to these authors, the 2-3 orders of magnitude higher BCF values for fluoxetine in G. pulex resulted from the limited depuration in these animals. Our results (Figures 2 and 3) also indicate low depuration of the tested pharmaceuticals from S. ambiguum. In the most cases, after transferring the protozoa to a fresh medium, the intracellular concentration decreased only $2-3$ times. The differences in the degree of uptake across the different organisms may be due to differences in the mode of respiration, behavior, and $\mathrm{pH}$ of the test system. Moreover, the BCF values are reduced as organism size increases and increase with increasing lipid content [34,35]. However, Rubach et al. [36] found no relationship between lipid content and chlorpyrifos uptake in all 15 species of fish they tested. Lipophilicity is the most often used criterion for predicting the bioaccumulation potential. According to European 
guidelines on environmental risk assessment of medicinal products for human use [37], all drug substances with $\log \mathrm{P}>4.5$ should be considered to be potentially persistent and should be screened for bioaccumulation; however, OECD uses lower criteria of only $\log \mathrm{P}>3$ [38]. Based on the calculated $\log \mathrm{P}$ values, Howard and Muir [13] classified sertraline, fluoxetine, and paroxetine as potentially bioaccumulative. However, at neutral $\mathrm{pH}$, the $\log \mathrm{D}$ values are much lower than $\log \mathrm{P}$ values (Table 1), and this can explain such low BCF values for fluoxetine $(\log$ D: $1.23-1.81)$ and paroxetine (log D: 0.01-0.61). Grabicova et al. [17] showed that the antidepressive drug citalopram tended to accumulate in organisms, and the extent of accumulation was equivalent to the extent of metabolic transformation and removal from the body.

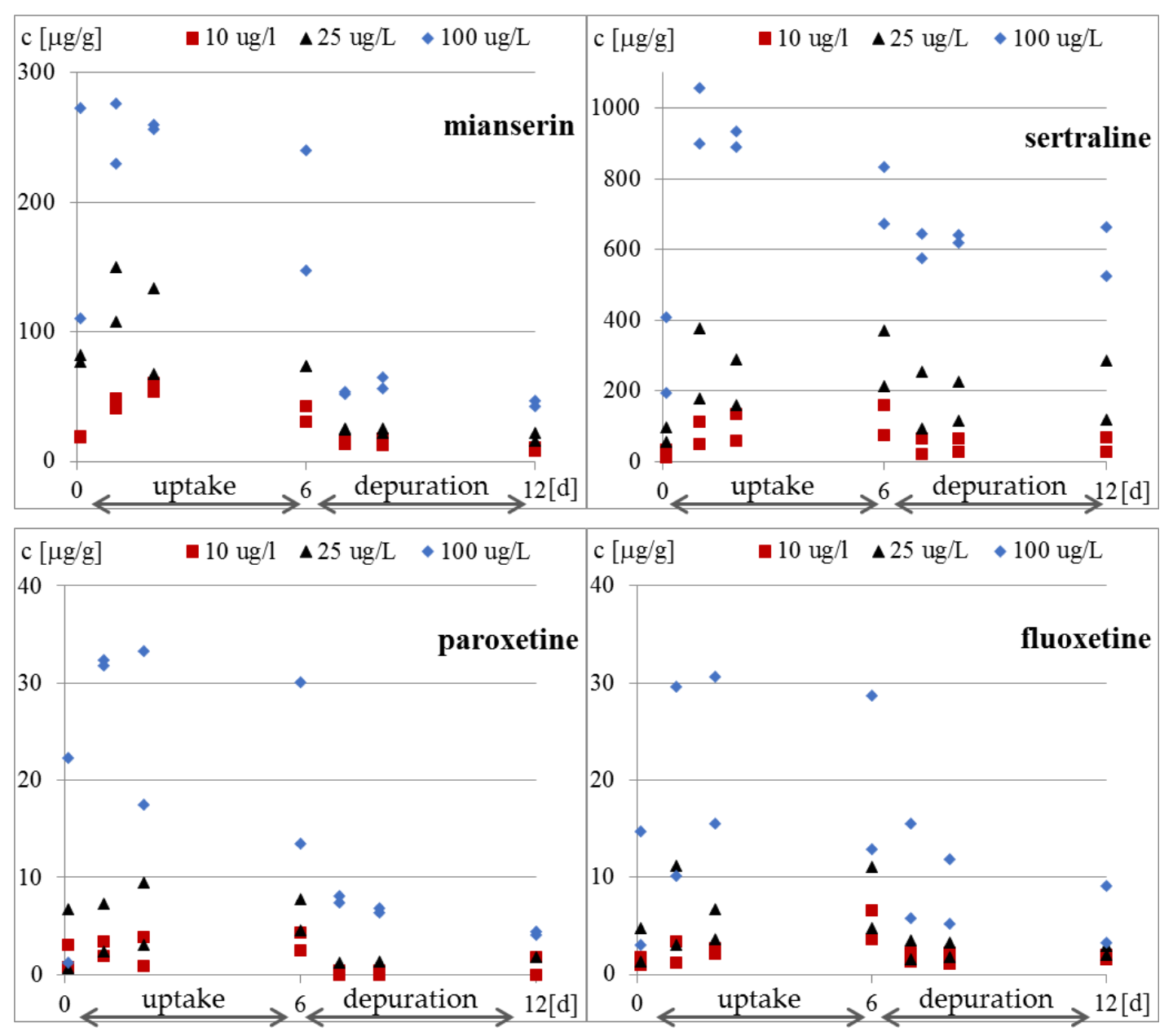

Figure 2. Concentration of tested antidepressants in S. ambiguum cells $[\mu \mathrm{g} / \mathrm{g}]$. 


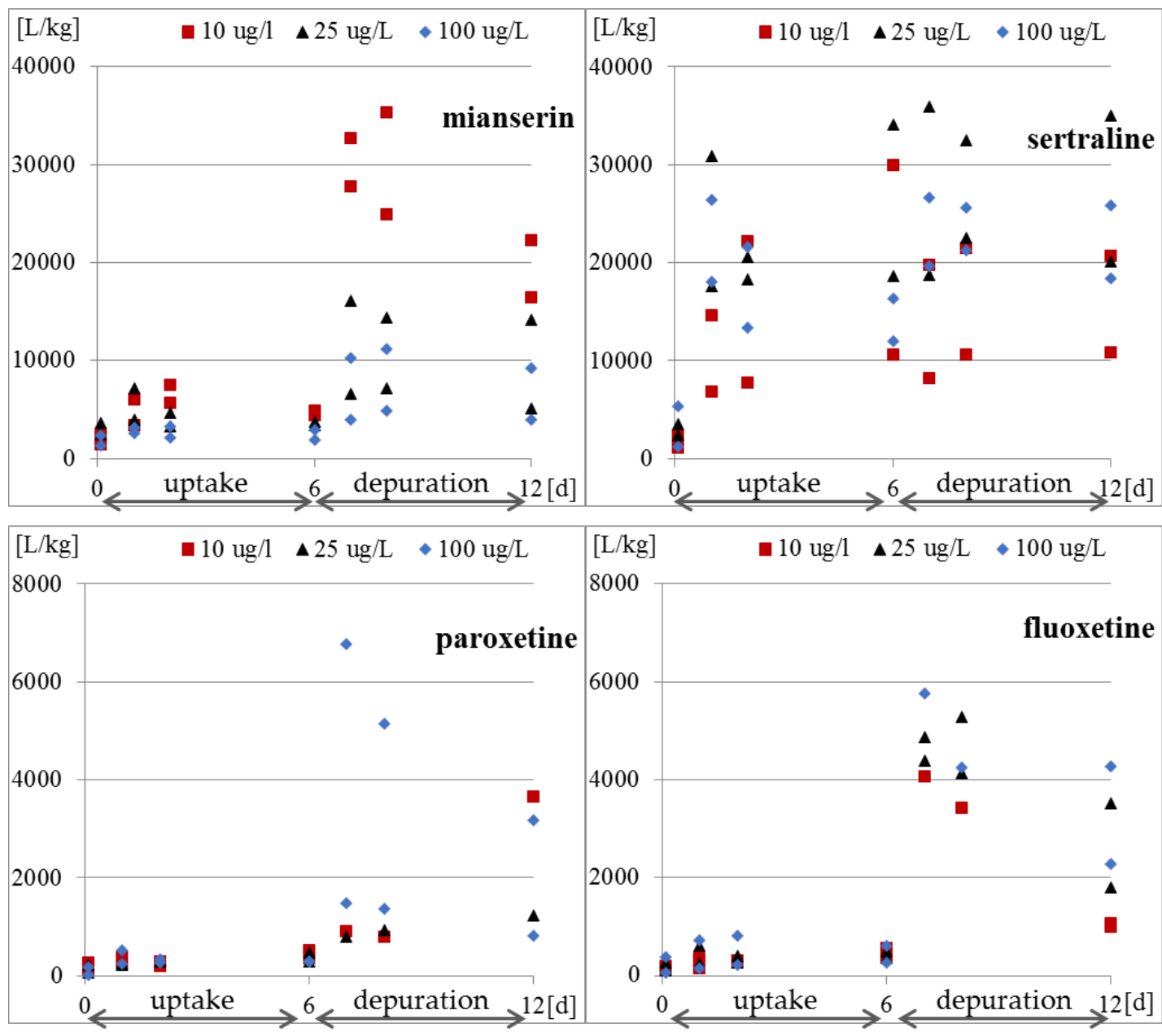

Figure 3. Bioconcentration factor expressed as the ratio of concentration of tested antidepressants in S. ambiguum cells to the concentration in water.

After transferring S. ambiguum to a clean solution, very slow elimination was observed, and the drugs were detected inside the cells at concentrations up to 11,000 higher than that in the water phase (Figure 3 and Table A3). This indicates that the protozoa were unable to excrete the accumulated antidepressants. The bioaccumulation of drugs in subcellular organelles may eventually result in phospholipidosis and alkalinization of the lysosomes [39]. Two mechanisms are responsible for the accumulation of the basic amphiphilic compounds in cells: binding to phospholipids and lysosomal trapping [40]. The cell membrane and membranes of cellular organelles are permeable to non-ionized compounds [39]. The most acidic $\mathrm{pH}$ of protozoa food vacuoles ranges between 3.5 and 4.0. In these conditions, all the tested antidepressants became protonated and cannot pass through the membrane back to the cytosol, which may result in their accumulation within the lysosomes [39]. This phenomenon is called lysosomotropism and has been found in different mammalian cells [39-41]. However, to the best of our knowledge, it has not yet been studied in protozoa. The degree of ion trapping depends on membrane permeability, the $\mathrm{pH}$ gradient between the cytosol and lysosome, and physicochemical properties of the compound such as pKa [41]. In our present study, vacuolization of the protozoan cells was observed after six days of incubation with the highest tested concentration of sertraline $(100 \mu \mathrm{g} / \mathrm{L})($ date not presented). This suggests an effect of the drug on vacuole membrane; however, this hypothesis needs to be confirmed in future research. 


\subsection{Biotransformation}

To evaluate biotransformation, the protozoan S. ambiguum was incubated with the antidepressant solution $(100 \mu \mathrm{g} / \mathrm{L})$ in darkness for two days. The Orbitrap ${ }^{\mathrm{TM}}$ high-resolution UPLC-MS/MS was used to determine the potential metabolites of the antidepressants in both medium and the protozoan cell. The tentative metabolites of the antidepressant were detected by Compound Discoverer Software (Thermo Fisher Scientific).

The tests were performed twice, and the relative area of the chromatogram peaks are presented in Table 2. The chromatograms of the tested samples were compared to that of the control samples. The peaks observed in two replicates of the samples and not visible in two controls were shown. The predicted transformation products and the difference between the measured and theoretical mass are given. As controls, the antidepressant solutions without the protozoa were incubated under the same conditions. No transformation products were observed in the control samples (data not presented), which confirms the previous findings that these compounds are stable in the aquatic environment $[42,43]$. Derivatives of only two drugs (fluoxetine and paroxetine) were detected in the protozoa homogenates, whereas four to six transformation products were observed in aquatic media for each antidepressant. The very low levels inside the protozoan cells may be caused by the method of sample preparation. Because of their very low volume, the cell homogenates were analyzed without any enrichment techniques, while the medium was concentrated 100-fold by passing it through Hydrophilic-Lipophilic Balance (HLB) cartridges. The lack of metabolites inside the cells could also be caused by their better solubility in water, high elimination rate from the cells, and lower bioconcentration in the cells than those of the parent compounds.

Table 2. Biotransformation of the tested antidepressants by S. ambiguum. Relative abundance of the compounds in the protozoan S. ambiguum and in the medium after two days incubation of the protozoans with the parent compounds. The test was performed in duplicate.

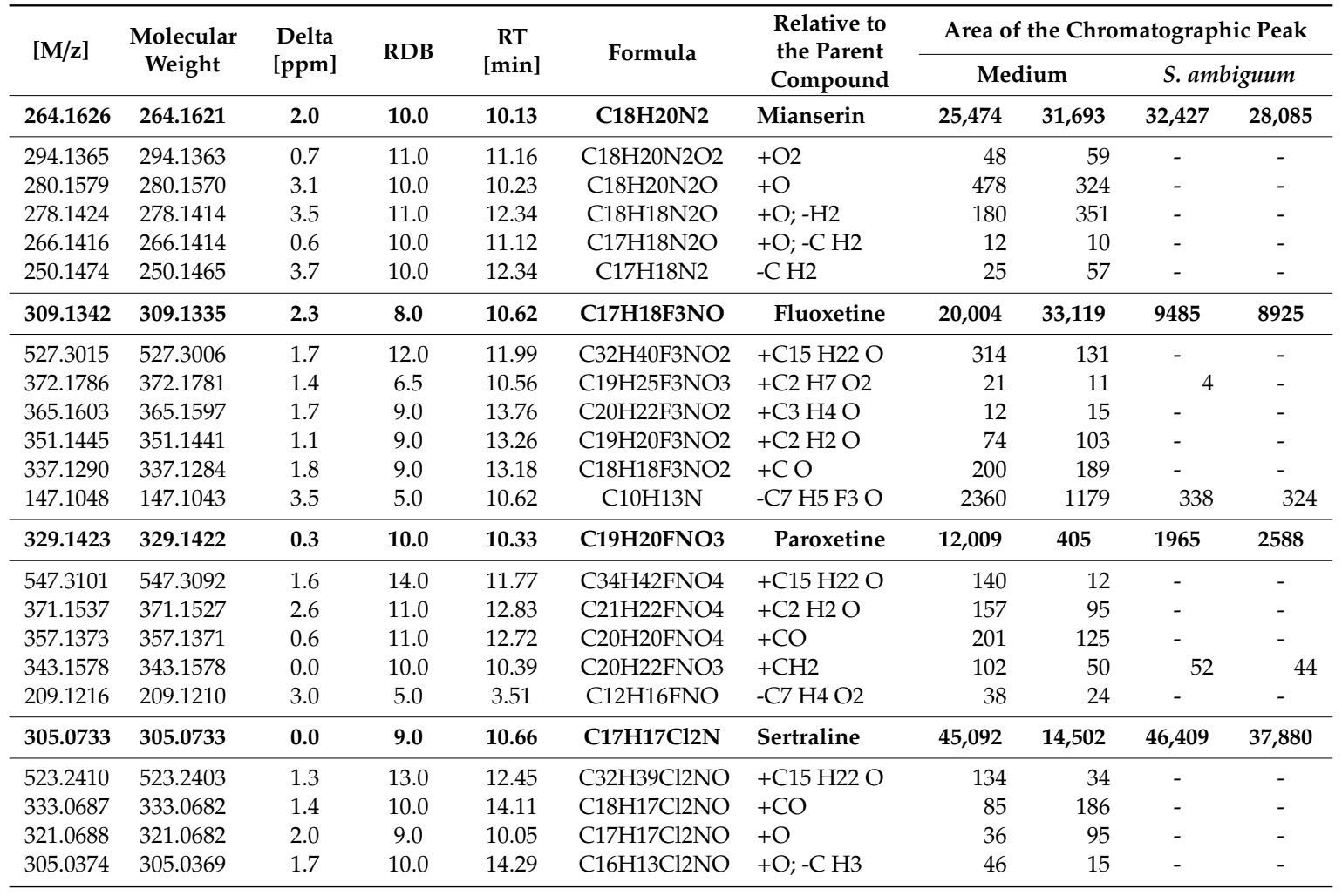

Five mianserin derivatives were observed in the tested samples, and these were N-demethylation and oxidation products (Table 2). The major mianserin metabolites that are formed in the liver in 
humans are N-desmethylmianserin, 8-hydroxymianserin and mianserin N-oxide (www.drugbank.ca). Similar products, formed probably by oxidation and oxidative desmethylation, were observed for sertraline, but not fluoxetine (Table 2). Because of the low abundance of these compounds, it was not possible to confirm their structure by fragmentation. Three main sertraline metabolites have been reported in humans: desmethylsertraline, sertraline ketone and sertraline N-carbamoyl glucuronide [44]. In humans, fluoxetine and sertraline are mainly metabolized to N-desmethyl products, which retain their pharmacological activity [18]. N-desmethyl metabolites were also found in aquatic organisms. Silva et al. [18] presented several findings on the occurrence of norfluoxetine and norsertraline in many freshwater fish. These metabolites are more stable than their parent compounds and less polar; thus, their levels in many cases were higher than those of their parent compounds, especially in the liver and brain. However, the authors did not provide the source of these metabolites in aquatic organisms. In organisms collected from the environment, the most probable source of these compounds was the accumulation of metabolites of human origin. Only laboratory tests can prove the occurrence of biotransformation processes in aquatic organisms. Rodriguez et al. [45] detected residual norsertraline in crab cultures incubated with sertraline for two days. Chu et al. [46] found increased concentrations of norfluoxetine in fish incubated with fluoxetine. The mussel M. galloprovincialis was exposed to a nominal concentration of fluoxetine $(75 \mathrm{ng} / \mathrm{L})$ for 15 days [47]. The authors observed that the concentration of fluoxetine and norfluoxetine increased from 2.53 and $3.06 \mathrm{ng} / \mathrm{g}$ dry weight after 3 days up to 9.31 and $11.65 \mathrm{ng} / \mathrm{g}$ after 15 days, respectively. These results suggest that fluoxetine accumulated in mussel tissues is likely to be metabolized into norfluoxetine with the increase in the time of exposure.

In humans, paroxetine is metabolized to paroxetine catechol, which is methylated and conjugated into second phase metabolites $[42,48]$. Cleavage of the paroxetine is also possible, which leads to the formation of the metabolite with a molecular mass of 209 Da [48]. The latter compound was also observed in our studies (Table 2).

Two identical derivatives of SSRIs were observed, which resulted from the addition of CO and C15H22O (Table 2). To the best of our knowledge, such transformation products have not been described either for humans or for aquatic organisms. Their structures were not proposed in the current study because of their very low abundance to perform fragmentation studies. However, this will be the subject of future studies.

\subsection{Ecological Implications}

The presence of pharmaceuticals in the environment, with a focus on their presence in water, is a potentially major problem with consequences such as toxicity and/or persistence that have not yet been fully understood. Simultaneously, studies involving topical exposure of protozoa to pharmaceuticals in the aquatic environment are very limited [49]. However, protozoa, next to bacteria, constitute the main group of organisms in activated sludge in WWTP, and they are involved in the removal of pollutants from waste-water [50] and in the freshwater self-purification process. Hence, they could have a significant role in removing drugs from the aqueous phase and in their transfer to higher trophic levels. Considering that neuroactive drugs are one of the most ecotoxic pharmaceuticals and that their removal efficiency depends on the condition of conventional activated sludge in WWTP, it is extremely important to know the mechanisms that enable the functioning of protozoa in such conditions and the potential for recovery after contamination. Acute toxicity results obtained in this study were two orders of magnitude higher than the SSRIs concentrations reported in environmental samples. Thus, it can be concluded that the tested antidepressants are unlikely to be toxic to the aquatic protozoa. On the other hand, according to our research and literature review, the SSRIs have been accumulated in biota, and long-term toxic effects cannot be excluded. Thus, future research should be focused on analyzing the transmission of toxic substances, e.g., pharmaceuticals accumulated in vacuoles, and/or their effects on the next generations of organisms and on the next links in the trophic chain. 


\section{Materials and Methods}

\subsection{Reagents}

Standards of fluoxetine (FLU) and mianserin (MNS) as well as internal standards (IS, nortryptyline and doxepin) were obtained from Sigma-Aldrich (Poznań, Poland), while paroxetine (PAR) and sertraline (SER) were gifts from the National Drug Research Institute, Warsaw, Poland. All the drugs were of high purity grade $(>90 \%)$. The standard stock solutions of all compounds were prepared in methanol at concentrations of $1 \mathrm{mg} / \mathrm{mL}$ and stored at $-20{ }^{\circ} \mathrm{C}$. Working solutions were prepared ex tempore by dilution of the stock solutions with the culture medium. IS working solution $(500 \mathrm{ng} / \mathrm{mL})$ was prepared ex tempore by dilution of the stock solution with acetonitrile. The solvents, namely HPLC gradient grade methanol, MS grade acetonitrile (LiChrosolv) and formic acid 98\%, were provided by Merck (Darmstadt, Germany). Ultrapure water was obtained from a Millipore water purification system (Milli-Q water). The $\mathrm{pH}$-dependent octanol-water partition coefficients (log D) were calculated with $\log \mathrm{D}$ predictor (https://disco.chemaxon.com/apps).

\subsection{Toxicity Assay}

Acute toxicity was determined according to the Spirotox assay procedure [1]. Briefly, the assay was performed in 24-well polystyrene microplates. Five 2-fold dilutions were prepared directly in the multi-well plate. Each well contained $1 \mathrm{~mL}$ of the test solution and 10 protozoan cells. The microplates were incubated at $25^{\circ} \mathrm{C}$ in darkness. Toxic effects (lethality, sublethal responses such as shortening, bending of the cell, immobilization) were noted after 1, 2, and 7 days of incubation. $\mathrm{LC}_{50}, \mathrm{EC}_{50}$ and $\mathrm{EC}_{20}$ values were calculated on the basis of lethal response (L) and all toxic effects (lethal and sublethal) (E), respectively. The toxicity values were expressed in $\mathrm{mg} / \mathrm{L}$ on the basis of the initial concentrations of the tested compounds. The $\mathrm{LC}_{50}, \mathrm{EC}_{50}$ and $\mathrm{EC}_{20}$ values were determined by graphical interpolation of test response versus toxicant concentration (log scale) [3]. As the diluent and control, Tyrod solution [1] buffered with $\mathrm{NaH}_{2} \mathrm{PO}_{4}$ and $\mathrm{Na}_{2} \mathrm{HPO}_{4}(50 \mathrm{mM})$ was used. The toxicity of each compound was tested at $\mathrm{pH} 6.0 ; 6.5$, and 7.4. All tests were performed in quadruplicate.

\subsection{Bioaccumulation Test}

The experiments were carried out in $250 \mathrm{~mL}$ glass beakers filled with $200 \mathrm{~mL}$ of sample or control. As a diluent and control, an inorganic medium (Tyrod solution) was used, with pH adjusted to 7.4. The bioaccumulation experiments were performed for the individual drugs: fluoxetine, sertraline, paroxetine, and mianserin $(10,25$ and $100 \mu \mathrm{g} / \mathrm{L})$. The experimental scheme is presented in Table 3. A total of 1000 protozoan cells were added to each beaker, and the beakers were incubated for 6 days $(144 \mathrm{~h})$ at $25{ }^{\circ} \mathrm{C}$ in darkness. A total of 100 protozoan cells were subsampled from each test beaker after $2 \mathrm{~h}$ and after 1, 2, and 6 days of incubation. Simultaneously, $1 \mathrm{~mL}$ of water from each sample was taken for chemical analysis. After 6 days, the protozoa (approximately 500) were transferred to a new glass beaker with the fresh Tyrod solution for testing the depuration of the accumulated drugs. Next, 100 protozoan cells and $1 \mathrm{~mL}$ of water were subsampled after 1,2, and 6 days of incubation. The test was performed in duplicate.

Table 3. Bioaccumulation experiment with protozoan S. ambiguum. During the sampling $1 \mathrm{~mL}$ of medium and 100 protozoans were collected for chemical analyses.

\begin{tabular}{ccccccccc}
\hline \multicolumn{2}{c}{ Preparation: } & \multicolumn{3}{c}{ Accumulation Phase } & \multicolumn{3}{c}{ Depuration Phase } \\
\hline & $0 \mathrm{~h}$ & $2 \mathrm{~h}$ & $1 \mathrm{~d}$ & $2 \mathrm{~d}$ & $6 \mathrm{~d}$ & $1 \mathrm{~d}$ & $2 \mathrm{~d}$ & $6 \mathrm{~d}$ \\
Medium & $+200 \mathrm{~mL}$ & $-1 \mathrm{~mL}$ & $-1 \mathrm{~mL}$ & $-1 \mathrm{~mL}$ & $-1 \mathrm{~mL}$ & $-1 \mathrm{~mL}$ & $-1 \mathrm{~mL}$ & $-1 \mathrm{~mL}$ \\
S. ambiguum & +1000 & -100 & -100 & -100 & -100 & -100 & -100 & -100 \\
\hline
\end{tabular}

Quantitative analyses were performed using Agilent 1260 Infinity (Agilent Technologies, Santa Clara, CA, USA), equipped with a degasser, a thermostated autosampler, a binary pump, 
and connected in series to a QTRAP ${ }^{\circledR} 4000$ (AB SCIEX, Framingham, MA, USA) equipped with a Turbo Ion Spray source operated in the positive mode. The curtain gas, ion source gas 1, ion source gas 2 and collision gas (all high purity nitrogen) were set at $35 \mathrm{psi}, 60 \mathrm{psi}, 40 \mathrm{psi}$ and 'medium' instrument units, respectively, and the ion spray voltage and source temperature were set at $5000 \mathrm{~V}$ and $600{ }^{\circ} \mathrm{C}$, respectively. Chromatographic separation was achieved with a Kinetex RP-18 column $(100 \mathrm{~mm}, 4.6 \mathrm{~mm}$, particle size $2.6 \mu \mathrm{m}$ ) supplied by Phenomenex (Torrance, CA, USA). The column was maintained at $40{ }^{\circ} \mathrm{C}$ at the flow rate of $0.5 \mathrm{~mL} / \mathrm{min}$. The mobile phases consisted of HPLC grade water with $0.2 \%$ formic acid as eluent $\mathrm{A}$ and acetonitrile with $0.2 \%$ formic acid as eluent $\mathrm{B}$. The gradient $(\% \mathrm{~B})$ was as follows: $0 \mathrm{~min}, 10 \% ; 1 \mathrm{~min}, 10 \% ; 8 \mathrm{~min}, 90 \% ; 9 \mathrm{~min}, 90 \%$. The volume of injection was $10 \mu \mathrm{L}$. The target compounds were analyzed in the multiple reaction monitoring (MRM) mode (Table A4) by monitoring two transitions between the precursor ion and the most abundant fragment ions for each compound.

Preparation of S. ambiguum samples for HPLC analysis involved mixing $50 \mu \mathrm{L}$ of sample (100 protozoan cells + medium) with IS $(50 \mu \mathrm{L})$ and acetonitrile $(100 \mu \mathrm{L})$. The samples were vortexed (10 $\mathrm{min}$ ), placed for $10 \mathrm{~min}$ in a freezer $\left(\right.$ at $-20^{\circ} \mathrm{C}$ ) and then centrifuged $(5 \mathrm{~min}$ at $10,000 \times \mathrm{g}$ ). The supernatant $(150 \mu \mathrm{L})$ was mixed with $375 \mu \mathrm{L}$ of water and transferred to the autosampler vial. The concentration of pharmaceuticals in organisms was calculated using the measured concentration of the pharmaceutical in the medium and the volume of S. ambiguum. An average volume of 100 cells of S. ambiguum was $0.50 \mu \mathrm{L}$. The preparation of medium samples for HPLC analysis involved centrifugation $(10 \mathrm{~min}$ at $10,000 \times g)$, mixing with the IS $(9: 1)$ and transferring to vials. No clean up procedure was used.

The validation was performed according to the European Medicines Agency guideline [37]. For S. ambiguum extracts, two linearity ranges were selected: $1-100 \mu \mathrm{g} / \mathrm{L}$ and $50-10,000 \mu \mathrm{g} / \mathrm{L}$ of homogenate. For medium samples, the linearity was selected as $0.2-100 \mu \mathrm{g} / \mathrm{L}$. The coefficients of determination for curves was above 0.99. All validation experiments (accuracy, precision, variation of the relative matrix effect and stability) met the European Medicines Agency (EMEA) acceptance criteria [51].

The concentration of the tested antidepressants in S ambiguum was expressed as $\mu \mathrm{g} / \mathrm{g}$ assuming the density of the organism as $1 \mathrm{~g} / \mathrm{mL}$. The bioconcentration factor was calculated by dividing the substance concentration in organisms to the concentration in the medium and was expressed as $\mathrm{L} / \mathrm{kg}$.

\subsection{Analysis of Biotransformation of Drugs}

The biotransformation of the drugs by the protozoa was analyzed for the four antidepressants: fluoxetine, mianserin, paroxetine, and sertraline. The test beakers were prepared in a manner similar to that for the bioaccumulation experiment. However, only one concentration $(100 \mu \mathrm{g} / \mathrm{L})$ of the drug was tested, and no depuration phase was performed. Concomitant with the tested sample, two control samples were incubated: the abiotic degradation control containing only the same concentration of the tested pharmaceutical (described as "drug control") and the organism control containing only protozoa. After 2 days of incubation in darkness, 500 protozoan cells in $100 \mu \mathrm{L}$ of medium were transferred to the Eppendorf tube, and $200 \mu \mathrm{L}$ of acetonitrile was then added. Samples were vortexed (10 min), placed for $10 \mathrm{~min}$ in the freezer $\left(\mathrm{at}-20^{\circ} \mathrm{C}\right)$ and centrifuged $(5 \mathrm{~min}$ at $10,000 \times \mathrm{g})$. The supernatant $(150 \mu \mathrm{L})$ was mixed with $375 \mu \mathrm{L}$ of water and transferred to the autosampler vial. Furthermore, $100 \mathrm{~mL}$ of medium was sampled at the end of experiment and poured into the preconditioned Oasis HLB (Waters) spe cartridge $(30 \mathrm{mg})$. The analytes were eluted with $2 \times 3 \mathrm{~mL}$ of methanol. The methanol was evaporated under the stream of nitrogen, and the extract was reconstituted with $1 \mathrm{~mL}$ of acetonitrile:water (1:9, $v / v)$. The analysis of transformation products was performed with Ultra High Performance Liquid Chromatography (UHPLC) Dionex Ultimate 3000 with a Q-Exactive hybrid quadrupole-orbitrap mass spectrometer system. Heat electrospray ionization (HESI) was operated in the positive mode. Full MS scans were acquired over $m / z 75-1100$ range with the resolution of 70,000 ( $\mathrm{m} / z \mathrm{200})$. Standard mass spectrometric conditions for all experiments were as follows: spray voltage: $3.5 \mathrm{kV}$; sheath gas pressure: $60 \mathrm{arb}$; aux gas pressure: $20 \mathrm{arb}$; sweep gas pressure: $0 \mathrm{arb}$; heated capillary temperature: 
$32{ }^{\circ} \mathrm{C}$; loop count: 3 ; isolation window: $\mathrm{m} / \mathrm{z} 3.0$; and dynamic exclusion: $6.0 \mathrm{~s}$. Chromatographic separation was achieved using a Kinetex RP-18 column $(100 \mathrm{~mm} \times 4.6 \mathrm{~mm}, 2.6 \mu \mathrm{m})$ supplied by Phenomenex and equipped with a security guard. The column was maintained at $40{ }^{\circ} \mathrm{C}$ at the flow rate of $0.3 \mathrm{~mL} / \mathrm{min}$. The mobile phases consisted of HPLC grade water with $0.1 \%$ formic acid as eluent $\mathrm{A}$ and acetonitrile with $0.1 \%$ formic acid as eluent $\mathrm{B}$. The gradient $(\% \mathrm{~B})$ was as follows: 0 min- $10 \%$; $1.5 \mathrm{~min}-10 \% ; 7.0 \mathrm{~min}-90 \% ; 12 \mathrm{~min}-90 \%$. The volume of injection was $10 \mu \mathrm{L}$.

All the chromatograms obtained in the biotransformation experiments were integrated with Compound Discoverer Software. The area of the peaks obtained for the sample (protozoa in the drug solution) was divided by the area of the corresponding peaks of the control (protozoa in the medium). Similarly, the area of the peaks obtained for the drug control was divided by the area of the corresponding peaks of the medium. Thus, three values were obtained: tested medium, extract from the protozoan cells, and control medium.

\section{Conclusions}

We successfully performed a laboratory experiment designed to obtain comprehensive results for acute toxicity, bioconcentration, and biotransformation by determining the biological activity of four antidepressants on the protozoan S. ambiguum. The tested compounds were acutely toxic to S. ambiguum, and moreover, sublethal effects quickly became lethal ones. Sertraline was the most toxic among the studied antidepressants. However, the toxic effects occur at concentrations at least two orders of magnitude higher than those determined in effluents and freshwaters. Thus, it can be concluded that the tested antidepressants are unlikely to represent a risk to the aquatic protozoa. The results also showed the relationship between $\mathrm{pH}$ and toxicity, which has two consequences. First, the $\mathrm{pH}$ of the water should be more strictly defined in the aquatic toxicity guidelines to prevent high inter- and intra-laboratory variability of the results. Second, $\mathrm{pH}$ of the water and effluent should be considered in the environmental risk assessment, especially for ionizable compounds.

On the basis on the bioconcentration tests, it can be concluded that uptake and elimination kinetics vary greatly between the tested pharmaceuticals. The highest BCF value was obtained for sertraline and mianserin, but different bioaccumulation scenarios can be observed for each pharmaceutical and for each concentration. Our results also indicate that the protozoan cells were unable to excrete the accumulated antidepressants. We suspect that the main reason of the toxic effects and high bioaccumulation ratio were the interactions between the tested drugs and lysosomal membrane phospholipids, which lead to vacuolization. Thus, future research should focus on analyzing the transmission of antidepressants accumulated in vacuoles and/or their effects on the next generations of organisms.

For the first time, the research for the biotransformation products of antidepressants were conducted in the protozoa. However, because of the low abundance of possible biotransformation products, their structure could not be elucidated. This part of the present work revealed a potential for further investigation of pharmaceutical metabolism in protozoa exposed to drugs under natural conditions.

Author Contributions: Conceptualization: A.D., G.N.-J. and M.W.; methodology: J.G., G.N.-J., A.D. and M.W.; formal analysis: J.G., G.N.-J., A.D. and M.W.; investigation: J.G., G.N.-J., A.D., M.W. and A.O.; resources: J.G., G.N.-J., A.D., M.W. and A.O.; data curation: J.G., G.N.-J., A.D. and M.W.; supervision: J.G., G.N.-J. and A.D.; writing - original draft preparation: J.G., G.N.-J., A.O.; A.D. and M.W.; writing-review and editing: J.G., G.N.-J., A.D., M.W. and A.O.; funding acquisition: G.N.-J.; project administration: G.N.-J.; All authors have read and agreed to the published version of the manuscript.

Funding: This research was financially supported by the Medical University of Warsaw (Grant number: FW14/N/2017). LC-MS/MS analysis on QTRAP was carried out using the CePT infrastructure financed by the European Union-the European Regional Development Fund within the Operational Program "Innovative economy" for 2007-2013.

Acknowledgments: The authors wish to thank Ryszard Marszałek for technical assistance during LC-MS/MS analysis.

Conflicts of Interest: The authors declare no conflict of interest. 


\section{Appendix A}

Table A1. Toxicity of the selected antidepressants in the Spirotox assay [mg/L].

\begin{tabular}{|c|c|c|c|c|}
\hline \multicolumn{2}{|c|}{ Fluoxetine } & $\mathrm{pH}=6.0$ & $\mathrm{pH}=6.5$ & $\mathrm{pH}=7.4$ \\
\hline \multirow{3}{*}{$1 \mathrm{~d}$} & $\mathrm{LC}_{50}$ & $5.13 \pm 0.41$ & $2.78 \pm 0.07$ & $1.73 \pm 0.17$ \\
\hline & $\mathrm{EC}_{50}$ & $4.75 \pm 0.23$ & $2.32 \pm 0.24$ & $1.68 \pm 0.19$ \\
\hline & $\mathrm{EC}_{20}$ & $2.03 \pm 0.82$ & $1.16 \pm 0.14$ & $1.21 \pm 0.04$ \\
\hline \multirow{3}{*}{$2 \mathrm{~d}$} & $\mathrm{LC}_{50}$ & $4.06 \pm 0.10$ & $1.78 \pm 0.46$ & $1.52 \pm 0.16$ \\
\hline & $\mathrm{EC}_{50}$ & $2.88 \pm 0.38$ & $1.49 \pm 0.14$ & $1.39 \pm 0.13$ \\
\hline & $\mathrm{EC}_{20}$ & $1.72 \pm 0.51$ & $0.98 \pm 0.16$ & $1.06 \pm 0.11$ \\
\hline \multirow{3}{*}{$7 \mathrm{~d}$} & $\mathrm{LC}_{50}$ & $2.03 \pm 0.55$ & $0.99 \pm 0.16$ & $1.35 \pm 0.07$ \\
\hline & $\mathrm{EC}_{50}$ & $1.94 \pm 0.53$ & $0.96 \pm 0.16$ & $1.05 \pm 0.22$ \\
\hline & $\mathrm{EC}_{20}$ & $0.86 \pm 0.15$ & $0.58 \pm 0.07$ & $0.70 \pm 0.13$ \\
\hline \multicolumn{2}{|c|}{ Mianserin } & $\mathrm{pH}=6.0$ & $\mathrm{pH}=6.5$ & $\mathrm{pH}=7.4$ \\
\hline \multirow{3}{*}{$1 \mathrm{~d}$} & $\mathrm{LC}_{50}$ & $6.43 \pm 0.16$ & $3.95 \pm 1.02$ & $2.64 \pm 0.50$ \\
\hline & $\mathrm{EC}_{50}$ & $6.27 \pm 0.09$ & $3.88 \pm 1.11$ & $2.35 \pm 0.33$ \\
\hline & $\mathrm{EC}_{20}$ & $3.34 \pm 0.76$ & $2.68 \pm 0.67$ & $1.58 \pm 0.40$ \\
\hline \multirow{3}{*}{$2 \mathrm{~d}$} & $\mathrm{LC}_{50}$ & $5.47 \pm 0.24$ & $3.51 \pm 1.28$ & $2.20 \pm 0.44$ \\
\hline & $\mathrm{EC}_{50}$ & $4.80 \pm 0.41$ & $3.34 \pm 1.23$ & $1.55 \pm 0.18$ \\
\hline & $\mathrm{EC}_{20}$ & $2.90 \pm 0.25$ & $2.70 \pm 0.59$ & $1.16 \pm 0.08$ \\
\hline \multirow{3}{*}{$7 \mathrm{~d}$} & $\mathrm{LC}_{50}$ & $3.56 \pm 0.76$ & $1.34 \pm 0.04$ & $1.42 \pm 0.07$ \\
\hline & $\mathrm{EC}_{50}$ & $2.75 \pm 0.57$ & $1.20 \pm 0.18$ & $1.32 \pm 0.12$ \\
\hline & $\mathrm{EC}_{20}$ & $2.05 \pm 0.23$ & $0.66 \pm 0.04$ & $1.01 \pm 0.18$ \\
\hline \multicolumn{2}{|c|}{ Paroxetine } & $\mathrm{pH}=6.0$ & $\mathrm{pH}=6.5$ & $\mathrm{pH}=7.4$ \\
\hline \multirow{3}{*}{$1 \mathrm{~d}$} & $\mathrm{LC}_{50}$ & $4.53 \pm 0.55$ & $1.40 \pm 0.06$ & $1.17 \pm 0.29$ \\
\hline & $\mathrm{EC}_{50}$ & $3.15 \pm 1.68$ & $1.37 \pm 0.03$ & $1.15 \pm 0.29$ \\
\hline & $\mathrm{EC}_{20}$ & $2.46 \pm 0.46$ & $1.05 \pm 0.05$ & $0.85 \pm 0.24$ \\
\hline \multirow{3}{*}{$2 \mathrm{~d}$} & $\mathrm{LC}_{50}$ & $2.55 \pm 0.75$ & $1.27 \pm 0.16$ & $1.15 \pm 0.30$ \\
\hline & $\mathrm{EC}_{50}$ & $2.07 \pm 0.73$ & $1.24 \pm 0.17$ & $1.10 \pm 0.29$ \\
\hline & $\mathrm{EC}_{20}$ & $1.71 \pm 0.30$ & $0.77 \pm 0.45$ & $0.85 \pm 0.24$ \\
\hline \multirow{3}{*}{$7 \mathrm{~d}$} & $\mathrm{LC}_{50}$ & $1.44 \pm 0.21$ & $0.81 \pm 0.31$ & $0.77 \pm 0.10$ \\
\hline & $\mathrm{EC}_{50}$ & $1.32 \pm 0.13$ & $0.76 \pm 0.26$ & $0.74 \pm 0.06$ \\
\hline & $\mathrm{EC}_{20}$ & $1.12 \pm 0.02$ & $0.44 \pm 0.16$ & $0.58 \pm 0.02$ \\
\hline \multicolumn{2}{|c|}{ Sertraline } & $\mathrm{pH}=6.0$ & $\mathrm{pH}=6.5$ & $\mathrm{pH}=7.4$ \\
\hline \multirow{3}{*}{$1 \mathrm{~d}$} & $\mathrm{LC}_{50}$ & $0.85 \pm 0.09$ & $0.47 \pm 0.11$ & $0.41 \pm 0.05$ \\
\hline & $\mathrm{EC}_{50}$ & $0.73 \pm 0.14$ & $0.42 \pm 0.08$ & $0.36 \pm 0.01$ \\
\hline & $\mathrm{EC}_{20}$ & $0.46 \pm 0.18$ & $0.28 \pm 0.04$ & $0.29 \pm 0.01$ \\
\hline \multirow{3}{*}{$2 \mathrm{~d}$} & $\mathrm{LC}_{50}$ & $0.49 \pm 0.10$ & $0.33 \pm 0.06$ & $0.35 \pm 0.01$ \\
\hline & $\mathrm{EC}_{50}$ & $0.39 \pm 0.12$ & $0.31 \pm 0.06$ & $0.35 \pm 0.02$ \\
\hline & $\mathrm{EC}_{20}$ & $0.19 \pm 0.03$ & $0.22 \pm 0.08$ & $0.29 \pm 0.01$ \\
\hline \multirow{3}{*}{$7 \mathrm{~d}$} & $\mathrm{LC}_{50}$ & $0.33 \pm 0.08$ & $0.18 \pm 0.04$ & $0.27 \pm 0.03$ \\
\hline & $\mathrm{EC}_{50}$ & $0.28 \pm 0.05$ & $0.17 \pm 0.03$ & $0.23 \pm 0.04$ \\
\hline & $\mathrm{EC}_{20}$ & $0.20 \pm 0.05$ & $0.13 \pm 0.03$ & $0.15 \pm 0.01$ \\
\hline
\end{tabular}


Table A2. Concentration of the tested antidepressants in S. ambiguum in $\mu \mathrm{g} / \mathrm{g}$.

\begin{tabular}{|c|c|c|c|c|c|c|}
\hline \multirow{2}{*}{$\begin{array}{l}\text { Fluoxetine } \\
\text { Sampling: }\end{array}$} & \multicolumn{2}{|c|}{$10 \mu \mathrm{g} / \mathrm{L}$} & \multicolumn{2}{|c|}{$25 \mu \mathrm{g} / \mathrm{L}$} & \multicolumn{2}{|c|}{$100 \mu \mathrm{g} / \mathrm{L}$} \\
\hline & 1 & 2 & 1 & 2 & 1 & 2 \\
\hline $0.083 \mathrm{~d}$ & 1.02 & 1.80 & 1.20 & 4.70 & 2.95 & 14.66 \\
\hline $1 \mathrm{~d}$ & 1.27 & 3.36 & 2.94 & 11.04 & 10.02 & 29.54 \\
\hline $2 \mathrm{~d}$ & 2.17 & 2.71 & 3.57 & 6.65 & 15.45 & 30.51 \\
\hline $6 \mathrm{~d}$ & 3.66 & 6.65 & 4.65 & 10.91 & 12.82 & 28.65 \\
\hline $7 \mathrm{~d}$ & 1.32 & 2.27 & 1.52 & 3.37 & 5.75 & 15.46 \\
\hline $8 \mathrm{~d}$ & 1.09 & 2.30 & 1.73 & 3.13 & 5.08 & 11.77 \\
\hline $12 \mathrm{~d}$ & 1.61 & 2.05 & 1.89 & 2.88 & 3.15 & 9.07 \\
\hline Mianserin & \multicolumn{2}{|c|}{$10 \mu \mathrm{g} / \mathrm{L}$} & \multicolumn{2}{|c|}{$25 \mu \mathrm{g} / \mathrm{L}$} & \multicolumn{2}{|c|}{$100 \mu \mathrm{g} / \mathrm{L}$} \\
\hline Sampling: & 1 & 2 & 1 & 2 & 1 & 2 \\
\hline $0.083 \mathrm{~d}$ & 19.88 & 18.37 & 81.76 & 76.13 & 110.04 & 272.27 \\
\hline $1 \mathrm{~d}$ & 48.43 & 40.66 & 148.83 & 107.07 & 229.05 & 275.21 \\
\hline $2 \mathrm{~d}$ & 54.28 & 60.35 & 66.51 & 132.7 & 256.15 & 259.24 \\
\hline $6 \mathrm{~d}$ & 30.32 & 42.43 & 72.79 & 72.59 & 146.31 & 239.26 \\
\hline $7 \mathrm{~d}$ & 16.39 & 13.88 & 24.21 & 24.71 & 51.36 & 52.78 \\
\hline $8 \mathrm{~d}$ & 17.68 & 12.49 & 21.55 & 24.79 & 56.04 & 63.88 \\
\hline $12 \mathrm{~d}$ & 11.29 & 8.23 & 21.29 & 15.04 & 46.07 & 42.08 \\
\hline Paroxetine & \multicolumn{2}{|c|}{$10 \mu \mathrm{g} / \mathrm{L}$} & \multicolumn{2}{|c|}{$25 \mu \mathrm{g} / \mathrm{L}$} & \multicolumn{2}{|c|}{$100 \mu \mathrm{g} / \mathrm{L}$} \\
\hline Sampling: & 1 & 2 & 1 & 2 & 1 & 2 \\
\hline $0.083 \mathrm{~d}$ & 0.72 & 3.01 & 0.61 & 6.75 & 1.27 & 22.33 \\
\hline $1 \mathrm{~d}$ & 1.89 & 3.36 & 2.36 & 7.33 & 32.43 & 31.86 \\
\hline $2 \mathrm{~d}$ & 0.84 & 3.85 & 3.03 & 9.46 & 17.45 & 33.26 \\
\hline $6 \mathrm{~d}$ & 2.49 & 4.34 & 4.50 & 7.78 & 13.46 & 30.14 \\
\hline $7 \mathrm{~d}$ & 0.45 & $<\mathrm{LOD}$ & 1.19 & $<\mathrm{LOD}$ & 7.44 & 8.12 \\
\hline $8 \mathrm{~d}$ & 0.40 & $<\mathrm{LOD}$ & 1.40 & $<\mathrm{LOD}$ & 6.90 & 6.38 \\
\hline $12 \mathrm{~d}$ & 1.82 & $<\mathrm{LOD}$ & 1.85 & $<\mathrm{LOD}$ & 4.11 & 4.42 \\
\hline Sertraline & \multicolumn{2}{|c|}{$10 \mu \mathrm{g} / \mathrm{L}$} & \multicolumn{2}{|c|}{$25 \mu \mathrm{g} / \mathrm{L}$} & \multicolumn{2}{|c|}{$100 \mu \mathrm{g} / \mathrm{L}$} \\
\hline Sampling: & 1 & 2 & 1 & 2 & 1 & 2 \\
\hline $0.083 \mathrm{~d}$ & 12.01 & 32.52 & 54.34 & 97.41 & 194.84 & 409.65 \\
\hline $1 \mathrm{~d}$ & 50.14 & 112.44 & 179.26 & 377.38 & 900.06 & 1058.73 \\
\hline $2 d$ & 58.24 & 135.65 & 161.30 & 290.20 & 890.58 & 935.23 \\
\hline $6 \mathrm{~d}$ & 75.49 & 159.08 & 212.90 & 371.61 & 673.24 & 832.82 \\
\hline $7 \mathrm{~d}$ & 22.06 & 65.37 & 94.85 & 255.51 & 574.47 & 645.00 \\
\hline $8 \mathrm{~d}$ & 28.55 & 66.59 & 116.04 & 227.17 & 641.16 & 619.90 \\
\hline $12 \mathrm{~d}$ & 27.22 & 68.21 & 120.04 & 286.69 & 525.78 & 664.49 \\
\hline
\end{tabular}


Table A3. Bioconcentration factor of the tested antidepressants in S. ambiguum in $\mathrm{L} / \mathrm{kg}$. The test was performed in duplicate.

\begin{tabular}{|c|c|c|c|c|c|c|}
\hline \multirow{2}{*}{$\begin{array}{l}\text { Fluoxetine } \\
\text { Sampling: }\end{array}$} & \multicolumn{2}{|c|}{$10 \mu \mathrm{g} / \mathrm{L}$} & \multicolumn{2}{|c|}{$25 \mu \mathrm{g} / \mathrm{L}$} & \multicolumn{2}{|c|}{$100 \mu \mathrm{g} / \mathrm{L}$} \\
\hline & 1 & 2 & 1 & 2 & 1 & 2 \\
\hline $0.083 \mathrm{~d}$ & 123 & 202 & 81 & 248 & 39 & 359 \\
\hline $1 \mathrm{~d}$ & 157 & 359 & 217 & 585 & 129 & 696 \\
\hline $2 \mathrm{~d}$ & 306 & 283 & 238 & 392 & 191 & 786 \\
\hline $6 \mathrm{~d}$ & 387 & 565 & 328 & 473 & 255 & 600 \\
\hline $7 \mathrm{~d}$ & 4079 & 11,267 & 4358 & 4859 & 11,122 & 5738 \\
\hline $8 \mathrm{~d}$ & 3439 & 9045 & 5259 & 4108 & 10,776 & 4228 \\
\hline $12 \mathrm{~d}$ & 1000 & 1065 & 3500 & 1779 & 4256 & 2257 \\
\hline Mianserin & \multicolumn{2}{|c|}{$10 \mu \mathrm{g} / \mathrm{L}$} & \multicolumn{2}{|c|}{$25 \mu \mathrm{g} / \mathrm{L}$} & \multicolumn{2}{|c|}{$100 \mu \mathrm{g} / \mathrm{L}$} \\
\hline Sampling: & 1 & 2 & 1 & 2 & 1 & 2 \\
\hline $0.083 \mathrm{~d}$ & 2320 & 1445 & 3666 & 2450 & 1395 & 2357 \\
\hline $1 \mathrm{~d}$ & 6092 & 3366 & 7190 & 4033 & 3138 & 2621 \\
\hline $2 \mathrm{~d}$ & 7497 & 5721 & 3276 & 4666 & 3318 & 2137 \\
\hline $6 \mathrm{~d}$ & 4381 & 4939 & 3772 & 3430 & 1885 & 2973 \\
\hline $7 \mathrm{~d}$ & 32,774 & 27,757 & 16,138 & 6648 & 10,271 & 4008 \\
\hline $8 \mathrm{~d}$ & 35,358 & 24,976 & 14,364 & 7201 & 11,208 & 4854 \\
\hline $12 \mathrm{~d}$ & 22,287 & 16,464 & 14,191 & 5169 & 9214 & 4004 \\
\hline Paroxetine & \multicolumn{2}{|c|}{$10 \mu \mathrm{g} / \mathrm{L}$} & \multicolumn{2}{|c|}{$25 \mu \mathrm{g} / \mathrm{L}$} & \multicolumn{2}{|c|}{$100 \mu \mathrm{g} / \mathrm{L}$} \\
\hline Sampling: & 1 & 2 & 1 & 2 & 1 & 2 \\
\hline $0.083 \mathrm{~d}$ & 130 & 267 & 54 & 221 & 18 & 171 \\
\hline $1 \mathrm{~d}$ & 389 & 280 & 214 & 247 & 523 & 252 \\
\hline $2 \mathrm{~d}$ & 189 & 290 & 281 & 324 & 349 & 277 \\
\hline $6 \mathrm{~d}$ & 524 & 357 & 482 & 281 & 293 & 286 \\
\hline $7 \mathrm{~d}$ & 905 & & 794 & & 1487 & 6770 \\
\hline $8 \mathrm{~d}$ & 806 & & 934 & & 1379 & 5148 \\
\hline $12 \mathrm{~d}$ & 3649 & & 1234 & & 823 & 3179 \\
\hline Sertraline & \multicolumn{2}{|c|}{$10 \mu \mathrm{g} / \mathrm{L}$} & \multicolumn{2}{|c|}{$25 \mu \mathrm{g} / \mathrm{L}$} & \multicolumn{2}{|c|}{$100 \mu \mathrm{g} / \mathrm{L}$} \\
\hline Sampling: & 1 & 2 & 1 & 2 & 1 & 2 \\
\hline $0.083 \mathrm{~d}$ & 1092 & 2374 & 2394 & 3516 & 1203 & 5383 \\
\hline $1 \mathrm{~d}$ & 6803 & 14,603 & 17,574 & 30,933 & 18,037 & 26,468 \\
\hline $2 \mathrm{~d}$ & 7745 & 22,238 & 18,351 & 20,582 & 13,352 & 21,649 \\
\hline $6 \mathrm{~d}$ & 10,573 & 30,015 & 18,643 & 34,092 & 12,033 & 16,362 \\
\hline $7 \mathrm{~d}$ & 8261 & 19,810 & 18,781 & 35,987 & 19,674 & 26,653 \\
\hline $8 \mathrm{~d}$ & 10,573 & 21,482 & 22,532 & 32,453 & 21,301 & 25,616 \\
\hline $12 \mathrm{~d}$ & 10,800 & 20,669 & 20,140 & 34,962 & 18,358 & 25,856 \\
\hline
\end{tabular}


Table A4. MS/MS optimized conditions for the analyzed compounds and internal standards.

\begin{tabular}{|c|c|c|c|c|c|c|c|c|}
\hline \multirow{2}{*}{$\begin{array}{c}{[M+H]^{+}} \\
\quad \text { Ion }\end{array}$} & \multirow{2}{*}{$\begin{array}{l}\text { Quantitative } \\
\text { Product Ion }\end{array}$} & \multirow{2}{*}{ Compound } & \multirow{2}{*}{$\begin{array}{l}D P \\
{[\mathrm{~V}]}\end{array}$} & \multirow{2}{*}{$\begin{array}{c}C E \\
{[\mathrm{~V}]}\end{array}$} & \multirow{2}{*}{$\begin{array}{c}C X P \\
{[\mathrm{~V}]}\end{array}$} & \multirow{2}{*}{$\begin{array}{l}\text { Qualitative } \\
\text { Product Ion }\end{array}$} & \multirow{2}{*}{$\begin{array}{c}C E \\
{[\mathrm{~V}]}\end{array}$} & \multirow{2}{*}{$\begin{array}{r}C X P \\
{[\mathrm{~V}]}\end{array}$} \\
\hline & & & & & & & & \\
\hline 280.1 & 107.0 & Doxepin & 71 & 33 & 6 & 235.1 & 25 & 14 \\
\hline 310.3 & 44.1 & Fluoxetine & 56 & 37 & 6 & 148.1 & 13 & 12 \\
\hline 265.1 & 208.0 & Mianserin & 96 & 31 & 12 & 118.0 & 43 & 8 \\
\hline 264.1 & 233.1 & Nortriptyline & 71 & 23 & 14 & 91.1 & 35 & 6 \\
\hline 330.2 & 192.1 & Paroxetine & 51 & 31 & 14 & 70.1 & 49 & 4 \\
\hline 306.0 & 158.9 & Sertraline & 51 & 35 & 12 & 275.0 & 19 & 16 \\
\hline
\end{tabular}

\section{References}

1. Nałęcz-Jawecki, G. Spirotox-Spirostomum ambiguum acute toxicity test-10 Years of experience. Environ. Toxicol. 2004, 19, 359-364. [CrossRef] [PubMed]

2. Nałęcz-Jawecki, G.; Demkowicz-Dobrzański, K.; Sawicki, J. Protozoan Spirostomum ambiguum as a highly sensitive bioindicator for rapid and easy determination of water quality. Sci. Total Environ. 1993, 134 (Suppl. 2), 1227-1234. [CrossRef]

3. Nałęcz-Jawecki, G. Spirotox test-Spirostomum ambiguum acute toxicity test. In Small-Scale Freshwater Toxicity Investigations. Volume 1-Toxicity Test Methods; Blaise, C., Férard, J., Eds.; Springer: New York, NY, USA, 2005; pp. 299-322.

4. Barbosa, M.O.; Ribeiro, A.R.; Ratola, N.; Hain, E.; Homem, V.; Pereira, M.F.R.; Blaney, L.; Silva, A.M.T. Spatial and seasonal occurrence of micropollutants in four Portuguese rivers and a case study for fluorescence excitation-emission matrices. Sci. Total Environ. 2018, 644, 1128-1140. [CrossRef] [PubMed]

5. Burns, E.E.; Carter, L.J.; Kolpin, D.W.; Thomas-Oates, J.; Boxall, A.B.A. Temporal and spatial variation in pharmaceutical concentrations in an urban river system. Water Res. 2018, 137, 72-85. [CrossRef] [PubMed]

6. Fernández, C.; González-Doncel, M.; Pro, J.; Carbonell, G.; Tarazona, J.V. Occurrence of pharmaceutically active compounds in surface waters of the henares-jarama-tajo river system (madrid, spain) and a potential risk characterization. Sci. Total Environ. 2010, 408, 543-551. [CrossRef] [PubMed]

7. Giebułtowicz, J.; Nałęcz-Jawecki, G. Occurrence of antidepressant residues in the sewage-impacted Vistula and Utrata rivers and in tap water in Warsaw (Poland). Ecotoxicol. Environ. Saf. 2014, 104, 103-109. [CrossRef]

8. Metcalfe, C.D.; Chu, S.; Just, C.; Li, H.; Oakes, K.D.; Servos, M.R.; Andrews, D.M. Antidepressants and their metabolites in municipal wastewater, and downstream exposure in an urban watershed. Environ. Toxicol. Chem. 2010, 29, 79-89. [CrossRef]

9. Paíga, P.; Santos, L.H.; Ramos, S.; Jorge, S.; Silva, J.G.; Delerue-Matos, C. Presence of pharmaceuticals in the Lis river (Portugal): Sources, fate and seasonal variation. Sci. Total Environ. 2016, 573, 164-177. [CrossRef]

10. Mole, R.; Brooks, B.W. Global scaning of selective serotonin reuptake inhibitors: Occurrence, wastewater treatment and hazards in aquatic systems. Environ. Pollut. 2019, 250, 1019-1031. [CrossRef]

11. Puckowski, A.; Mioduszewska, K.; Łukaszewicz, P.; Borecka, M.; Caban, M.; Maszkowska, J.; Stepnowski, P. Bioaccumulation and analytics of pharmaceutical residues in the environment: A review. J. Pharm. Biomed. Anal. 2016, 127, 232-255. [CrossRef]

12. Brooks, B.W.; Turner, P.K.; Stanley, J.K.; Weston, J.J.; Glidewell, E.A.; Foran, C.M.; Slattery, M.; La Point, T.W.; Huggett, D.B. Waterborne and sediment toxicity of fluoxetine to select organisms. Chemosphere 2003, 52, 135-142. [CrossRef]

13. Howard, P.H.; Muir, D.C.G. Identifying new persistent and bioaccumulative organics among chemicals in commerce II: Pharmaceuticals. Environ. Sci. Technol. 2011, 45, 6938-6946. [CrossRef] [PubMed]

14. Brooks, B.W.; Chambliss, K.C.; Stanley, J.K.; Ramirez, A.; Banks, K.E.; Johnson, R.D.; Lewis, R.J. Determination of selected antidepressants in fish from effluent-dominated stream. Environ. Toxicol. Chem. 2005, 24, 464-469. [CrossRef] [PubMed] 
15. Schultz, M.M.; Painter, M.M.; Bartell, S.E.; Logue, A.; Furlong, E.T.; Werner, S.L.; Schoenfuss, H.L. Selective uptake and biological consequences of environmentally relevant antidepressant pharmaceutical exposures on male fathead minnows. Aquat. Toxicol. 2011, 104, 38-47. [CrossRef] [PubMed]

16. Burket, S.R.; White, M.; Ramirez, A.J.; Stanley, J.K.; Banks, K.E.; Waller, W.T.; Chambiliss, C.K.; Brooks, B.W. Corbicula fluminea rapidly accumulate pharmaceuticals in an effluent dependent urban steam. Chemosphere 2019, 224, 873-883. [CrossRef] [PubMed]

17. Grabicova, K.; Grabic, R.; Blaha, M.; Kumar, V.; Cerveny, D.; Fedorova, G.; Randak, T. Presence of pharmaceuticals in benthic fauna living in a small stream affected by effluent from a municipal sewage treatment plant. Water Res. 2015, 72, 145-153. [CrossRef] [PubMed]

18. Silva, L.J.G.; Pereira, A.M.P.T.; Meisel, L.M.; Lino, C.M.; Pena, A. Reviewing the serotonin reuptake inhibitors (SSRIs) footprint in the aquatic biota: Uptake, bioaccumulation and ecotoxicology. Environ. Pollut. 2015, 197, 127-143. [CrossRef] [PubMed]

19. Heuett, N.V. Target and Non-Target Techniques for the Quantitation of Drugs of Abuse, Identification of Transformation Products, and Characterization of Contaminants of Emergent Concern by High-Resolution Mass Spectrometry. Ph.D. Thesis, Florida International University, Miami, FL, USA, 2015; p. 2194. [CrossRef]

20. Nałęcz-Jawecki, G. Evaluation of the in vitro biotransformation of fluoxetine with HPLC, mass spectrometry and ecotoxicological tests. Chemosphere 2007, 70, 29-35. [CrossRef]

21. Nałęcz-Jawecki, G.; Sawicki, J. Influence of $\mathrm{pH}$ on the toxicity of nitrophenols to Microtox and Spirotox tests. Chemosphere 2003, 52, 249-252. [CrossRef]

22. Bearden, A.P.; Schultz, T.W. Structure-activity relationships for Pimephales and Tetrahymena: A mechanism of action approach. Environ. Toxicol. Chem. 1997, 16, 1311-1317. [CrossRef]

23. Minguez, L.; Di Poi, C.; Farcy, E.; Ballandonne, C.; Benchouala, A.; Bojic, C.; Cossu-Leguille, C.; Costil, K.; Serpentini, A.; Lebel, J.; et al. Comparison of the sensitivity of seven marine and freshwater bioassays as regards antidepressant toxicity assessment. Ecotoxicology 2014, 23, 1744-1754. [CrossRef] [PubMed]

24. Kaiser, M.; Maser, P.; Tadoori, L.P.; Ioset, J.-R.; Brun, R. Antiprotozoal activity profiling of approved drugs: A starting point toward drug repositioning. PLoS ONE 2015, 10, e135556. [CrossRef] [PubMed]

25. Palit, P.; Ali, N. Oral therapy with sertraline, a selective serotonin reuptake inhibitor, shows activity against Leishmania donovani. J. Antimicrob. Chemother. 2008, 61, 1120-1124. [CrossRef] [PubMed]

26. Henry, T.B.; Kwon, J.-W.; Armbrust, K.L.; Black, M.C. Acute and chronic toxicity of five selective serotonin reuptake inhibitors in Ceriodaphnia dubia. Environ. Toxicol. Chem. 2004, 23, 2229-2233. [CrossRef]

27. Minagh, E.; Hernan, R.; O’Rourke, K.; Lyng, F.M.; Davoren, M. Aquatic ecotoxicity of the selective serotonin reuptake inhibitor sertraline hydrochloride in a battery of freshwater test species. Ecotox. Environ. Saf. 2009, 72, 434-440. [CrossRef]

28. Christensen, A.M.; Faaborg-Andersen, S.; Ingerslev, F.; Baun, A. Mixture and single-substance toxicity of selective serotonin reuptake inhibitors toward algae and crustaceans. Environ. Toxicol. Chem. 2007, 26, 85-91. [CrossRef]

29. Nałęcz-Jawecki, G.; Szczęsny, Ł.; Solecka, D.; Sawicki, J. Short ingestion tests as alternative proposal for conventional range finding assays with Thamnocephalus platyurus and Brachionus calyciflorus. Int. J. Environ. Sci. Technol. 2011, 8, 687-694. [CrossRef]

30. Wawryniuk, M.; Pietrzak, A.; Nałęcz-Jawecki, G. Evaluation of direct and indirect photodegradation of mianserin with high-performance liquid chromatography and short-term bioassays. Ecotoxicol. Environ. Saf. 2015, 115, 144-151. [CrossRef]

31. Stanley, J.K.; Ramirez, A.J.; Chambliss, C.K.; Brooks, B.W. Enantiospecific sublethal effects of the antidepressant fluoxetine to a model aquatic vertebrate and invertebrate. Chemosphere 2007, 69, 9-16. [CrossRef]

32. Du, B.; Haddad, S.P.; Scott, W.C.; Chambliss, C.K.; Brooks, B.W. Pharmaceutical bioaccumulation by periphyton and snails in an effluent-dependent stream during an extreme drought. Chemosphere 2015, 119, 927-934. [CrossRef]

33. Franzellitti, S.; Buratti, S.; Capolupo, M.; Du, B.; Haddad, S.P.; Chambliss, C.K.; Brooks, B.W.; Fabbri, E. An exploratory investigation of various modes of action and potential adverse outcomes of fluoxetine in marine mussels. Aquat. Toxicol. 2014, 151, 14-26. [CrossRef] [PubMed]

34. Meredith-Williams, M.; Carter, L.J.; Fussell, R.; Raffaelli, D.; Ashauer, R.; Boxall, A.B. Uptake and depuration of pharmaceuticals in aquatic invertebrates. Environ. Pollut. 2012, 165, 250-258. [CrossRef] [PubMed] 
35. Hendriks, A.J.; Linde, A.V.D.; Cornelissen, G.; Sijm, D.T.H.M. The power of size. 1. Rate constants and equilibrium ratios for accumulation of organic substances related to octanol-water partition ratio and species weight. Environ. Toxicol. Chem. 2001, 20, 1339-1420. [CrossRef]

36. Rubach, M.N.; Baird, D.J.; Van den Brink, P.J. A new method for ranking mode specific sensitivity of freshwater arthropods to insecticides and its relationship to biological traits. Environ. Toxicol. Chem. 2010, 29, 476-487. [CrossRef]

37. EMA/CHMP. European Medicines Agency/Committee for Medicinal Products for Human use. In Guideline on Bioanalytical Method Validation; EMEA/CHMP/EWP/192217/2009; European Medicines Agency: London, UK, 2011. Available online: http://www.ema.europa.eu/docs/en_GB/document_library/ (accessed on 4 December 2017).

38. OECD. Test No. 315: Bioaccumulation in Sediment-dwelling Benthic Oligochaetes. In OECD Guidelines for the Testing of Chemicals; Section 3; OECD Publishing: Paris, France, 2008. [CrossRef]

39. Lemieux, B.; Percival, M.D.; Falgueyret, J.-P. Quantitation of the lysosomotropic character of cationic amphiphilic drugs using the fluorescent basic amine Red DND-99. Anal. Biochem. 2004, 327, 247-251. [CrossRef] [PubMed]

40. Daniel, W.A.; Wójcikowski, J.; Pałucha, A. Intracellular distribution of psychotropic drugs in the grey and white matter of the brain: The role of lysosomal trapping. Br. J. Pharmacol. 2001, 134, 807-814. [CrossRef]

41. Kuzu, O.F.; Toprak, M.; Noory, M.A.; Robertson, G.P. Effect of lysosomotropic molecules on cellular homeostasis. Pharmacol. Res. 2017, 117, 177-184. [CrossRef]

42. Kwon, J.-W.; Armbrust, K.L. Hydrolysis and photolysis of paroxetine, a selective serotonin reuptake inhibitor, in aqueous solutions. Environ. Toxicol. Chem. 2004, 23, 1394-1399. [CrossRef]

43. Kwon, J.-W.; Armbrust, K.L. Laboratory persistence and fate of fluoxetine in aquatic environments. Environ. Toxicol. Chem. 2006, 25, 2561-2568. [CrossRef]

44. Obach, R.S.; Cox, L.M.; Tremaine, L.M. Sertraline is metabolized by multiple cytochrome P450 enzymes, monoamine oxidases, and glucuronyl transferases in human: An in vitro study. Drug Metab. Dispos. 2005, 33, 262-270. [CrossRef]

45. Rodriguez, A.P.; Santos, L.H.M.L.M.; Ramalhosa, M.J.; Delerue-Matos, C.; Guimaraes, L. Sertraline accumulation and effects in the estuarine decapod Cacinus maenas: Impotrance of the history of exposure to chemical stress. J. Hazard. Mater. 2015, 283, 250-358. [CrossRef]

46. Chu, S.; Metcalfe, C.D. Analysis of paroxetine, fluoxetine and norfluoxetine in fish tissues using pressurized liquid extraction, mixed mode solid phase extraction cleanup and liquid chromatography-tandem mass spectrometry. J. Chromatogr. A 2007, 1163, 112-118. [CrossRef] [PubMed]

47. Silva, L.J.G.; Martins, M.C.; Pereira, A.M.P.T.; Meisel, L.M.; Gonzalez-Rey, M.; Bebianno, M.J.; Lino, C.M.; Pena, A. Uptake, accumulation and metabolization of the antidepressant fluoxetine by Mytilus galloprovincialis. Environ. Pollut. 2016, 213, 432-437. [CrossRef] [PubMed]

48. Jornil, J.; Jensen, K.G.; Larsen, F.; Linnet, K. Identification of cytochrome P450 isoforms involved in the metabolism of paroxetine and estimation of their importance for human paroxetine metabolism using a population-based simulator. Drug Metab. Dispos. 2009, 38, 376-385. [CrossRef] [PubMed]

49. Wawryniuk, M.; Drobniewska, A.; Sikorska, K.; Nałęcz Jawecki, G. Influence of photolabile pharmaceutical on the photodegradation and toxicity of fluoxetine and fluvoxamine. Environ. Sci. Pollut. Res. 2018, 25, 6890-6898. [CrossRef] [PubMed]

50. Babko, R.; Kuzmina, T.; Suchorab, Z.; Widomski, M.K.; Franus, M. Influence of treated sewage dis charge on the bentos ciliate assembly in the lowland river. Ecol. Chem. Eng. S 2016, 23, 461-471. [CrossRef]

51. EMEA/CHMP. European Medicines Agency/Committee for Medicinal Products for Human use. In Guideline on the Environmental Risk Assessment of Medicinal Products for Human Use; EMEA/CHMP/SWP/4447/00 corr 1; European Medicines Agency: London, UK, 2006. Available online: http://www.ema.europa.eu/docs/en_GB/ document_library/ (accessed on 4 December 2017).

Sample Availability: Samples of the compounds are available from the authors.

(C) 2020 by the authors. Licensee MDPI, Basel, Switzerland. This article is an open access article distributed under the terms and conditions of the Creative Commons Attribution (CC BY) license (http://creativecommons.org/licenses/by/4.0/). 